\title{
The Ottoman Endgame: War, Revolution and the Making of the Modern Middle East, 1908-1923
}

Review Number: 1886

Publish date: Thursday, 4 February, 2016

Author: Sean McMeekin

ISBN: 9781846147050

Date of Publication: 2015

Price: $£ 20.40$

Pages: 576pp.

Publisher: Allen Lane

Publisher url: http://www.penguin.co.uk/books/the-ottoman-endgame/9780718199722/

Place of Publication: London

Reviewer: Kate Fleet

This is a curate's egg book, good in parts but distinctly not in others. On sure footing among the British, Russian and German protagonists of his narrative, the author, despite the title of his book and its time frame, from the Young Turk Revolution in 1908 to the creation of the Turkish Republic in 1923, slides unhappily around in the Ottoman world only to lose his footing entirely in the post-1918 era.

Divided into three parts, 'The Sick Man of Europe', 'The war of 1914: Turkey plays its hand' and 'Death and rebirth', the book begins with an introduction on 'The Sykes-Picot myth and the modern Middle East'. In it the author calls into question the significance of the Sykes-Picot agreement and argues, as he does elsewhere in the book, that in fact Sykes and Picot 'played second and third fiddle' (p. xviii) to the Russian foreign minister Sergei Sazonov and that the agreement should more accurately be called the Sazonov-SykesPicot agreement (p. 286), noting that Sykes, a 'diplomatic amateur if there ever was one', was out of his depth (p. 285). McMeekin then begins the narrative of the book with a brief prologue on 1876 and the accession of the Ottoman Sultan Abdülhamid II. Part one of the book covers the period from 1876 up to 1914 and deals with the reign of Abdülhamid II, the Young Turk Revolution of 1908, the Ottoman war with Italy in North Africa, and the Balkan Wars. Part three examines the situation after the war, covering the ensuing settlements of Mudros and Sèvres and the Turkish National War of Liberation, and ends with an epilogue, 'Lausanne and the Ottoman legacy'.

Part two begins with the assassination of Archduke Franz Ferdinand and his wife, the Duchess of Hohenberg and gives a gripping account of the well-known escape of the Goeben and the Breslau. It then proceeds through the various campaigns of the war, starting with Basra, Suez and Sar?kam??, McMeekin describing Enver Pa?a's Caucasian offensive of December 1914 as having 'a certain air of mystery' about it 'because it so egregiously violated common sense' (p. 145). McMeekin handles the issue of the Armenian massacres well, seeking to present a fine balance and to avoid political posturing. Perhaps the most interesting chapter of this section is that on the Dardanelles. Here McMeekin explains how the Russian Grand Duke Nicholas's 'passive-aggressive burbling was transformed into a full-blown strategic-diplomatic initiative' (p. 164).

Grand Duke Nicholas's request to the British military attaché Major General Sir John Hanbury-Williams for a British diversionary strike against the Ottomans at the time of the Ottoman offensive in the Caucasus had 
been received enthusiastically by Hanbury-Williams but any such idea should, McMeekin argues, have been shelved after the disaster of Sar?kam??. This did not, however, happen for 'it was already too late for a rethink' (p. 165) and the planning for a Dardanelles diversion went ahead. McMeekin argues that 'had Churchill and Kitchener been thinking sequentially in terms of regional and inter-Allied strategy' they would have launched an attack not on the Dardanelles but on Alexandretta (pp. 171-2). Had they done this, a separate peace with the Ottomans 'would ...certainly have followed', leaving the Turks with a rump state 'more or less in its actual borders settled in 1923' (p. 172). The reason this 'eminently logical' option was not taken, McMeekin suggests, was because it 'may have been too small-scale - too easy - to appeal to Kitchener and Churchill in their search for a grand move on the global chessboard' (p. 173). Churchill's neglect of the Cilician option was in part political, for he was anxious to keep his 'suspicious' French allies happy (p. 174). A factor in the British decision to go ahead, with the issue of ground troops still unresolved, was the British belief in the panic which would result in Istanbul when news reached of the attack in the Dardanelles, Grey apparently being convinced that a revolution would break out there, a belief he based on Kitchener's intimate knowledge of 'the Turkish psychology' but not on any knowledge Sir Louis Mallet, appointed British Ambassador at Istanbul in 1913, might have possessed, having not bothered to ask him (p. 178). McMeekin's conclusion on the British Dardanelles campaign was the rather bleak one that 'In essence ... Churchill, Grey, and Kitchener would make things up as they went along' (p. 180).

While the British, Russian and German protagonists emerge well, due in large part to McMeekin's use of Russian, German and British archival material (allowing him, for example, to make the interesting comparison between Russian intelligence (good) and British intelligence (bad) about the situation in the Dardanelles), the same cannot be said for the Ottomans. However, given the title of the book, The Ottoman Endgame, one can reasonably assume that it will bring an Ottoman dimension to this particular account. This assumption of an Ottoman-centric approach, or at least a view of the period in which the Ottomans are centre-stage, is strengthened by the author's remark at the beginning of the book that all translations from Turkish, unless otherwise stated, are his own (p. xiv). It is therefore something of a disappointment to find that in a book of nearly 600 pages apparently no Ottoman primary material has been used, despite the appearance in the bibliography of Ba?bakanl?k Osmanl? Ar?ivi (BOA, the Ottoman archives in Istanbul) and the ATASE archives (Genelkurmay Askeri Tarih ve Stratejik Etüt ve Denetleme Ba?kanl??? Ar?ivi , the military archives in Ankara). Given the subject of the book, it is more than surprising that the Turkish military archives are not utilised. Much ATASE material has in fact been published, and even here very little use indeed has been made of such sources. McMeekin makes no use at all of newspapers, many of which are now easily accessible thanks to the digitization of the Hakk? Tar?k Us collection, nor does he use memoires from the period, an increasing number of which are published, in particular by ?? Bankas? Kültür Yay?nlar?. 
There are practically no references in the footnotes to any secondary works in Turkish. The two exceptions are Sina Ak?in's introductory history, Ana Çizgileriyle Türkiye'nin Yak?n Tarihi 1789-1980, the English version of which, Turkey: from Empire to Revolutionary Republic: The Emergence of the Turkish Nation from 1789 to the Present, was published by Hurst in 2007, and Vahdet Kele?y?lmaz's book on the Indian mission of the Special Organization, the Te?kilat-? Mahsusa (which appears incorrectly in McMeekin's text as Te?kilat-i-Mahsûsa).(1) The enormous literature in Turkish on this period thus remains untapped here. Instead, McMeekin relies heavily on secondary works in English, including David Fromkin, A Peace to End All Peace: the Fall of the Ottoman Empire and the Creation of the Modern Middle East. Many of these works are general histories, such as Stanford J. Shaw and Ezel Kural Shaw's History of the Ottoman Empire and Modern Turkey. Volume II, Reform, Revolution, and Republic. The Rise of Modern Turkey 1808-1975, and Philip Mansel's Constantinople. City of the World's Desires, 1453-1924. Oddly, although he refers often to ?ükrü Hanio?lu's A Brief History of the Late Ottoman Empire, he does not refer to his very large and detailed Preparation for a Revolution. The Young Turks, 1902-1908 nor (apart from one reference) to Hanio?lu's other major work on the period, The Young Turks in Opposition, instead referring to Ernest Edmondson Ramsaur, The Young Turks: Prelude to the Revolution of 1908. For Abülhamid II he uses Joan Haslip, The Sultan: the Life of Abdul Hamid II, first published in 1958, a work that itself makes no use of Ottoman or Turkish material.(1)

In the chapters dealing with the Ottomans before 1914, McMeekin is not on sure footing. He refers to the first Ottoman parliament 'comprising some fourteen different nationalities' (p. 18), talks of 'Turkish secularists' (p. 51) in 1908, and regards the European powers as 'nursing the Sick Man back to health' (p. 23). His unawareness of the realities of the Ottoman world in the era of the 1908 revolution are made abundantly clear by his remark about the appearance on the streets of more and more assertive unveiled women like Halidé Edip (very oddly spelt this way throughout the text) (p. 51). What was significant here was the increasing politicization of Ottoman women, who had in fact been politically active before, not that they were unveiled (which they were not). The Ottomans, McMeekin tells us, held onto Tripolitania and Cyrenaica 'for mostly sentimental reasons' (p. 63) and refers to the 'intellectual turn towards assertive (and exclusive) Turkish nationalism' (p. 84) without any attempt to present a more nuanced, or more convincing, assessment. Later, he notes that Selim the Grim was 'notorious for Sunni sectarianism' (p. 114) and that 'The Hamidian revival of the empire's pan-Islamic credentials had been ... an unwitting recognition of declining Ottoman prestige in the modern era' (p. 294). If nothing else, Abdülhamid's policy can very rarely be described as unwitting.

Very oddly, McMeekin refers to an aide-de-camp of the grand vezir K?br?sl? Mehmed Kamil Pa?a in 1913 as Captain Kibrisli (sic, p. 77), which is clearly not his correct name but which McMeekin appears to have taken from Philip Mansel (Constantinople, p. 367), who also refers to Captain Kibrisli. Presumably the man meant here was K?br?sl? Tevfik Bey. McMeekin also has a problem with another name, that of a man he refers to as Arif Bey O?lu and, subsequently, simply as O?lu (which means son of) (p. 37), clearly incorrect.

While McMeekin is on unsure ground in the pre-First World War Ottoman world, the ground becomes increasingly shaky with the end of hostilities and the lead up to the creation of the Turkish Republic. The use of Russian and German material, which contributed considerably to sustaining the narrative for the World War chapters, is lacking here, as is, of course, any Ottoman or Turkish material. McMeekin's judgements about, for example, Rauf [Orbay], that he was 'very anglophile', that 'having been trained by English naval officers ... [he] had taken fully on board notions of British "gentlemanliness" and "fair play"” (p. 405) and that he was completely not up to the task of negotiations at Mudros with Calthorpe, would ring better if they were referenced to something other than Gwinne [sic] Dyer's 1972 article, 'The Turkish armistice of 1918'. There is no account of British activities in 1919 and 1920 in south eastern Anatolia, nothing about the use of air reconnaissance during the National War of Liberation, nor about the actual conditions on the ground in Anatolia in this period.

Instead the chapters contain startling errors. The important Ottoman commander, Ali ?hsan Pa?a, who was 
present at the fall of Mosul and was a source of much irritation to the British, who had him removed to Malta, appears as Ali Insan Pasha (pp. 310, 311, 354). When Mustafa Kemal left Samsun, his arrival there on 19 May 1919 being taken as the beginning of the National Liberation War and celebrated as a national holiday in Turkey, he went, so McMeekin tells us, to Hamza. This was in fact Havza. During the National War of Liberation, one of the significant battles was the second battle of ?nönü, conducted under the command of ?smet Pa?a (whom McMeekin never actually informs the reader was to become Prime Minister of Turkey, and President after the death of Mustafa Kemal Atatürk) who 'now took the name Ismet Inönü [sic]' (p. 451), something that he did not in fact do until 1934 with the introduction of the surname law.

McMeekin's footing falters entirely in the epilogue. Here he explains that the new Republic was the empire reborn (p. 479), Lausanne is hardly remembered today (p. 485), the economy of Turkey did not get going until the time of Turgut Özal (who became Prime Minister in 1983) and that culturally Turkey has never recovered (p. 486). When talking about the exchange of populations, McMeekin makes the statement that 'enough Greeks were permitted to remain in the city [Istanbul] so as to allow it to function' (p. 487), a statement pure common sense would lead one to question. Most bizarrely, McMeekin writes that 'one can understand why Mustafa Kemal decided not to contest Mosul against the British' (p. 493). In fact, the Turks hotly contested Mosul, the issue being decided finally by the League of Nations in 1926. In relation to the Arab territories, he refers to the 'lament for the fall of the Ottomans' in Arabic-speaking countries, a lament 'one can certainly understand' (p. 488). This seems to be because the minorities were better off under the Ottomans, although this part of the book is particularly incoherent, hampered by an apparent total ignorance over what in fact the reaction to the creation of the Turkish Republic was in the ex-Arab provinces. There is no discussion about the perception in, for example Palestine and Egypt, of Mustafa Kemal as a hero who stood up against imperialism. Nor is there any discussion of the impact of the end of the caliphate, nor of Turkey's position towards the Arab world, nor any discussion of the fact that in reality Turkey's new neighbours to the south were not Arab states but British and French mandates. He asserts that 'the fall of the Ottomans ushered in a time of troubles for the Middle East' (p. 489), and then moves swiftly into a list. Quite how the link works between the fall of the Ottomans and 1948 or the civil war in Lebanon is, not perhaps surprisingly, not made clear. This is a world in which the author is clearly very much out of his depth. 
One striking aspect of this book, a book which purports to deal with Ottoman and Turkish history, is the very sloppy approach to language. McMeekin's use of Ottoman and Turkish terms and names is inconsistent throughout the text. Thus Ottoman names sometimes appear in Arabized versions (e.g. Abdul Hamid II, rather than Abdülhamid, Abdul Mecid, Abdul Kerim Pasha) and sometimes not (e.g. Sabahaddin and Mehmed VI (Vahdettin)). Sometimes they are given in Turkish (e.g. ?emsi) and sometimes not (e.g. Shevket, Sultan Mehmed Reshad and Reshid Pasha), as is also the case with the term çete which appears as both chete and çete (a term which McMeekin does not explain). The same name appears in one place in Turkish spelling and in another in Arabic, as is the case with Tevfik/Tewfik, or in a strange mixture of both (e.g. Naz?m ?akir Bachreddin). This is also true of place names (e.g. Haydarpasha but Sar?kam??) and Çhe?me (which also appears correctly as Çe?me), while others are simply given odd spellings (e.g. Okmeidan, Diarbak?r, Kharput, Ere?li and Rumeli Kavak). There is no consistency over the use of $\mathrm{d}$ or $\mathrm{t}$ at the end of names (e.g. sometimes Ahmet and at others Ahmed). Some names appear in very odd spellings, such as Djemal Bey, Djavid Bey, Halidé Edip, and Djevdet, who also appears as Cevdet, the ships the Reshadieh, the Messudieh, and the Medjedieh, which also appears as the Mecidiye, and the torpedo boat the Gairet. There are also a large number of spelling mistakes in Turkish, and incorrect translations. Valide Sultan (the title of the reigning sultan's mother) is translated as 'harem mother', the Rescript of the Rose Bower is given as the translation for Hatt-? ?erif, although in fact the rose bower part (Gülhane) is missing here in the Turkish, Hatt-i Hümayun is given as Reform Edit, although the actual Turkish for that is Islahat Ferman?, Heyet-i Islahiye Reisi is translated as The German Reform Mission (in fact it means the head of the reform committee), while Çanakkale deniz zaferi is translated as Naval Triumph at the Dardanelles Day and described as a national holiday, held on $18 \mathrm{March}$. It is neither a national holiday nor is the translation correct, the actual phrase meaning Çanakkale naval victory.

To return to the curate and his egg, Sean McMeekin's book is well written, makes good use of Russian, German and British sources and contributes interesting arguments about the First World War. But if, misled by the title, the reader wishes to learn something about the Ottomans or to gain any insights into Ottoman thinking or to understand how it was that the Turkish Republic emerged from the rubble of the World War, then this is not the book to read.

\section{Notes}

1. Sina Ak?in, Ana Çizgileriyle Türkiye'nin Yak?n Tarihi 1789-1980 (Ankara, 1998); Sina Ak?in, Turkey: from Empire to Revolutionary Republic: The Emergence of the Turkish Nation from 1789 to the Present (London, 2007); Vahdet Kele?y?lmaz, Te?kilat? Mahsusa'n?n Hindistan Misyonu (19141918) (1999). Back to (1)

2. David Fromkin, A Peace to End All Peace: the Fall of the Ottoman Empire and the Creation of the Modern Middle East (New York, NY, 1989); Stanford J. Shaw and Ezel Kural Shaw, History of the Ottoman Empire and Modern Turkey. Volume II, Reform, Revolution, and Republic. The Rise of Modern Turkey 1808-1975 (Cambridge, 1977); Philip Mansel, Constantinople. City of the World's Desires, 1453-1924 (London, 1995); ?ükrü Hanio?lu, A Brief History of the Late Ottoman Empire (Princeton, NJ 2008); ?ükrü Hanio?lu, Preparation for a Revolution. The Young Turks, 1902-1908 (Oxford, 2001); ?ükrü Hanio?lu, The Young Turks in Opposition (Oxford, 1995); Ernest Edmondson Ramsaur, The Young Turks: Prelude to the Revolution of 1908 (Princeton, NJ, 1957); Joan Haslip, The Sultan: the Life of Abdul Hamid II (1958). Back to (2)

Source URL:https://reviews.history.ac.uk/review/1886

\section{Links}

[1] https://reviews.history.ac.uk/item/147906 